\title{
SELF-TESTING FOR HIV AMONG PARTNERS OF NEWLY DIAGNOSED HIV PERSONS - THE PILOT PROGRAM OF TEST AND KEEP IN CARE (TAK) PROJECT
}

\author{
PILOTAŻOWY PROJEKT SAMODZIELNEGO TESTOWANIA W KIERUNKU HIV \\ PARTNERÓW PACJENTÓW Z NOWO WYKRYTYM ZAKAŻENIEM HIV W RAMACH \\ PROJEKTU: „TEST AND KEEP IN CARE (TAK)”
}

\author{
${ }^{1}$ Foundation of Social Education, Warsaw \\ Fundacja Edukacji Społecznej \\ ${ }^{2}$ Department of Adults' Infectious Diseases, Medical University of Warsaw \\ HIV Outpatient Clinic, Regional Hospital for Infectious Diseases in Warsaw \\ Klinika Chorób Zakaźnych dla Dorosłych, Warszawski Uniwersytet Medyczny, \\ Poradnia Profilaktyczno-Lecznicza Wojewódzki Szpital Zakaźny w Warszawie
}

\begin{abstract}
OBJECTIVE. The objective of this study is to conduct a pilot program for self-testing for HIV during the SARS-CoV-2 pandemic. The target population was the partners of newly diagnosed HIV persons. The premise of the program was to offer such partners a test that they could perform in the conditions, at the time, and with the assistance of persons they themselves selected.

MATERIAL AND METHODS. The self-test kits were sent to an outpatient clinic providing care for people living with HIV, where, after taking a preliminary history, the physician who treats the newly diagnosed HIV patients handed them over for use by the partner of the patient. Only the persons who reported having relations with their sexual partner were included in the study. Information on whether the partner accepted the test kit and the self-test result were obtained at the subsequent visit.

RESULTS AND DISCUSSION. Between June 2020 and March 2021, the total number of handed out test kits was 48 kits intended for 24 persons, included 11 women, average age of participants: 35, sexual orientation: 20 persons reported heterosexual orientation, two persons reported homosexual orientation, two failed to provide information on their sexual orientation. All persons tested negative. The pilot program found that self-testing kits are a method for HIV screening in partners of newly diagnosed HIV persons that is simple to apply and easy to accept.
\end{abstract}

Key words: SARS-CoV-2, HIV, self-testing

\section{STRESZCZENIE}

CEL PRACY. Celem pracy było przeprowadzenie pilotażowego programu umożliwiającego samodzielne testowanie w kierunku HIV w czasie pandemii SARS-CoV-2. Populację docelową stanowili partnerzy osób z nowo rozpoznanym zakażeniem HIV. Założeniem programu było zaoferowanie wykonania testu partnerom tych osób w warunkach, czasie i asyście osób wybranych przez osobę testującą się.

MATERIAŁ I METODY. Testy do samodzielnego wykonania zostały przekazane do poradni specjalistycznej sprawującej opiekę medyczną nad osobami żyjącymi z HIV, gdzie lekarz prowadzący osoby z nowo zdiagnozowanym zakażeniem HIV po wstępnym wywiadzie przekazywał test dla partnera osoby konsultowanej. Pod uwagę brane były jedynie osoby deklarujące utrzymywanie dalszego kontaktu z partnerem seksualnym. Informacja na temat akceptacji i wyniku testu do samodzielnego wykonania uzyskiwana była na kolejnej wizycie.

(C) National Institute of Public Health NIH - National Research Institute / Narodowy Instytut Zdrowia Publicznego PZH - Państwowy Instytut Badawczy 
WYNIKI I ICH OMÓWIENIE. W okresie od czerwca 2020 r. do marca 2021 r. łącznie przekazano 48 testów dla 24 osób, w tym 11 kobiet, średnia wieku badanych: 35 lat, orientacja seksualna: 20 osób zadeklarowało orientację heteroseksualną, dwie osoby homoseksualną, $\mathrm{u}$ dwóch nie podano informacji o orientacji. Wszystkie osoby, które wykonały test uzyskały wynik ujemny. W przeprowadzonym programie pilotażowym testy do samodzielnego wykonania okazały się łatwą do zaakceptowania i nieskomplikowaną w przeprowadzeniu metodą do screeningu zakażenia HIV w grupie partnerów seksualnych pacjentów z nowo wykrytym zakażeniem HIV.

Slowa kluczowe: SARS-CoV-2, HIV, samodzielne testowanie

\section{INTRODUCTION}

Restricted access to healthcare during the SARSCoV-2 pandemic also translated to limited access to HIV testing $(1,2)$. From March to June 2020, all Counselling and Testing Centres that offer free and anonymous HIV tests were closed. When they reopened, many introduced restrictions such as testing by appointment only. This largely affected the number of HIV testing appointment slots. It also limited the access to free and anonymous HIV testing for partners of HIV positive patients.

The testing system involving free and anonymous tests with post-test counselling has been in place in Poland for over 20 years. Post-test counselling was introduced for fear that a patient who tests positive for HIV would not be able to deal with such a difficult situation and would require support (3).

Popularising various testing methods is instrumental in increasing the number of tested people, as only approximately $10 \%$ of adult Poles have ever undergone HIV testing (4). In Europe, at-home HIV test kits are available at pharmacies and chemists. Access to testing not only at healthcare providers but also quick and easy access, especially for key populations, e.g. at pharmacies and chemists, has been proposed for years. A fast diagnosis in those populations is essential to stop the spread of HIV $(5,6)$. Self-testing kits are a simple and easily accessible HIV screening method. Reliable results are available 12 weeks after risk-taking for HIV transmission.

Since, during the SARS-CoV-2 outbreak, HIV testing was not available at the Counselling and Testing Centres, a different, more accessible form of testing had to be introduced that would allow testing of newly diagnosed HIV persons as well as their partners. The care provided by outpatient clinics that care for people living with HIV does not extend to their partners; often, as young, previously healthy persons, they are not receiving regular medical care.

In many European countries, at-home HIV test kits have been available for years (7). Their effectiveness and efficiency have been confirmed by international bodies such as the World Health Organisation (WHO) (8).

\section{WSTĘP}

Ograniczenia w dostępie do opieki medycznej w czasie pandemii SARS-CoV-2 przełożyły się także na dostęp do diagnostyki w kierunku HIV $(1,2)$. Od marca do czerwca 2020 wszystkie Punkty Konsultacyjno-Diagnostyczne, gdzie wykonywane są bezpłatne i anonimowe testy w kierunku HIV, były zamknięte. Po ich ponownym otwarciu w wielu punktach wprowadzono restrykcje, jak np. zapisy na konkretną godzinę, co znacząco wpłynęło na zmniejszenie liczby osób mogących wykonać test w kierunku HIV. Partnerzy osób zdiagnozowanych także mieli ograniczone możliwości anonimowego i bezpłatnego testowania w kierunku HIV.

System testowania opierający się na bezpłatnym i anonimowym testowaniu z poradnictwem okołotestowym funkcjonuje w Polsce od ponad 20 lat. Podstawą do wprowadzenia poradnictwa okołotestowego była obawa, że osoba, która otrzyma wynik dodatni testu nie poradzi sobie z tak trudną sytuacją i będzie potrzebowała wsparcia (3).

Upowszechnienie różnych form testowania jest niezbędne do zwiększenia liczby osób wykonujących badania, gdyż tylko około $10 \%$ dorosłych Polaków wykonało test na HIV w ciągu życia (4). W Europie testy w kierunku HIV do samodzielnego wykonania dostępne są w aptekach i drogeriach. Od lat postuluje się dostęp do badań nie tylko w placówkach ochrony zdrowia, ale również łatwy i prosty dostęp do testów np. w aptece czy drogerii, szczególnie dla populacji kluczowych. Szybka diagnoza w tych populacjach jest niezbędna dla zatrzymania rozprzestrzeniania się zakażenia HIV $(5,6)$. Testy do samodzielnego wykonania są prostą i przystępną metodą skriningu w kierunku zakażenia HIV. Wiarygodny wynik można otrzymać po wykonaniu testu po 12 tygodniach od sytuacji ryzykownej.

Brak możliwości wykonania testu w kierunku HIV w punktach konsultacyjno-diagnostycznych w czasie pandemii SARS-CoV-2, wymagał uruchomienia innej, dostępnej formy dającej możliwość wykonania testu także partnerom osób z nowo rozpoznanym zakażeniem. Partnerzy nie są objęci opieką w poradni zajmującej się osobami żyjącymi z HIV, często również, 
The Polish AIDS Society recommends access to diversified forms of HIV testing. According to the recommendations, due to a large percentage of people unaware of their HIV infection, especially in key populations, as well as various barriers to access to HIV screening, it is recommended to introduce athome HIV test kits (9).

\section{OBJECTIVE}

The study aimed to introduce self-testing kits and verify their application in the population of sexual partners of newly diagnosed HIV persons.

\section{MATERIAL AND METHODS}

100 Simplitude $^{\mathrm{TM}} \mathrm{ByMe}^{\mathrm{TM}} \mathrm{HIV}$ self-tests were purchased (Original name: Atomo HIV Self Test Atomo Diagnostics, Australia). They are recommended for rapid diagnostic testing by the WHO (https:// unitaid.org/assets/HIVST-landscape-report.pdf 9.06.2020). The test involves pricking the finger and transferring the blood sample to the indicated well on the test cassette. Next, the buffer is added and, after 15 minutes, the test result is read. Each test kit contained a leaflet in Polish.

The self-test kits were sent to an outpatient clinic providing care for people living with HIV, where, after taking a preliminary history, the physician who treats the newly diagnosed HIV patients handed them over for use by the partner of the patient. The pilot program inclusion criterion was receiving a first confirmed Western Blot result in the last 12 months. During the next visit, the physician collected patient feedback on whether the patient's partner performed the test, if he or she had any problems administering it, and what the result of the test was.

The pilot program included an anonymous questionnaire gathering participants' basic information that was filled in by an infectious diseases physician electronically based on the data provided by the HIV person. The questionnaire contained questions regarding the sex, age, sexual orientation, the time elapsed since the risk situation, forms of risk behaviour (sexual contact, injecting drugs, or contact with blood) and any previous HIV tests. The questionnaire did not include questions regarding other past sexually transmitted diseases.

Every person received two HIV testing kits (48 tests in total, Table I). The test kit included instructions on its use and a number to a free HIV testing helpline operated by the Foundation of Social Education. Through the helpline, each study participant could obtain detailed information on how to perform the jako osoby młode i dotychczas zdrowe, nie są pod stałą opieką medyczną.

W wielu krajach europejskich testy do samodzielnego wykonania są już od lat dostępne (7). Ich skuteczność i efektywność potwierdziły międzynarodowe instytucje takie jak Światowa Organizacja Zdrowia (WHO) (8).

Polskie Towarzystwo Naukowe AIDS rekomenduje dostęp do zróżnicowanych form diagnostyki w kierunku HIV. Jak wskazują rekomendacje, w związku z dużym odsetkiem osób nieświadomych zakażenia HIV, szczególnie w populacjach kluczowych, oraz różnego rodzaju barierami w dostępie do badań przesiewowych w kierunku zakażenia HIV, zaleca się wprowadzenie testów do samodzielnego wykonania w warunkach domowych (9).

\section{CEL PRACY}

Celem pracy było wprowadzenie testów do samodzielnego wykonania i sprawdzenie ich zastosowania w populacji partnerów seksualnych osób z nowo rozpoznanym zakażeniem HIV.

\section{MATERIAŁ I METODY}

Zakupiono 100 testów do samodzielnego wykonania w kierunku HIV Simplitude TM ByMe TM (Oryginal name: Atomo HIV Self Test - Atomo Diagnostics, Australia). Są one rekomendowane przez WHO do szybkiej diagnostyki (https://unitaid.org/assets/HIVST-landscape-report.pdf 9.06.2020). Badanie polega na nakłuciu palca i nakropieniu krwi na wskazane miejsce na płytce testu. Następnie zakrapla się bufor i po 15 minutach odczytuje się wynik. Każdy test zawierał ulotkę w języku polskim.

Testy zostały przekazane do poradni specjalistycznej prowadzącej opiekę nad osobami żyjącymi z HIV. Lekarz prowadzący osoby z nowo zdiagnozowanym zakażeniem HIV, po wstępnym wywiadzie, przekazywał testy dla partnera osoby objętej opieką. Kryterium włączenia do pilotażowego badania było otrzymanie u osoby będącej pacjentem poradni pierwszego potwierdzonego wyniku Western Blot w ciągu ostatnich 12 miesięcy. Przy kolejnej wizycie lekarz uzyskiwał informację zwrotną od pacjenta, czy jego partner wykonał test, czy były jakiekolwiek trudności w jego wykonaniu oraz jaki był wynik testu.

Do pilotażowego badania opracowany został anonimowy kwestionariusz zbierający podstawowe informacje o osobie wykonującej test, wypełniany w formie elektronicznej przez lekarza chorób zakaźnych na podstawie informacji przekazanych przez osobę zakażoną HIV, będącą pacjentem poradni. Kwestionariusz zawierał pytania na temat płci, wieku, orientacji 
test and correctly interpret its results. If the result was reactive, help was offered.

\section{RESULT}

Between June 2020 and March 2021, the tests were offered and provided to 24 people, inculuding 11 women and 11 men, two participants did not disclose their sex. (Table II).

Table I. Number of provided tests and results obtained Tabela I. Liczba przekazanych testów i uzyskanych informacji o wyniku

\begin{tabular}{|c|c|c|}
\hline $\begin{array}{c}\text { Number of } \\
\text { provided tests }\end{array}$ & $\begin{array}{c}1 \text { test } \\
\text { performed }\end{array}$ & $\begin{array}{c}2 \text { tests } \\
\text { performed }\end{array}$ \\
\hline 48 & 11 & 1 \\
\hline Result & $\begin{array}{c}11 \text { negative } \\
\text { results }\end{array}$ & $\begin{array}{c}2 \text { negative } \\
\text { results }\end{array}$ \\
\hline
\end{tabular}

The study covered persons over 18 years of age. The average age of participants was 35 years (23-68). The study inclusion criterion was having a partner living with HIV who was receiving care from an acquired immunodeficiency syndrome outpatient clinic. The viral load was detectable in three HIV infected persons [VL: 39 (copies 1030 (copies/ml), 7200000 (copies $/ \mathrm{ml}$ )]. In addition to the test kit, all partners of the HIV persons also received information on other forms of differential prophylaxis, including pre-exposure prophylaxis and post-exposure prophylaxis (PrEP, PEP), using a condom, especially if the partner's HIV viral load is detectable. The participants also received a leaflet containing information on the PARTNER study and the $\mathrm{U}=\mathrm{U}$ campaign (Undetectable $=$ Untransmittable).

Among the persons who received the testing kits, 20 participants reported heterosexual orientation, two reported a homosexual orientation, and two did not provide information on their sexual orientation (Table II). Among the persons who received the self-testing kits, $11(46 \%)$ had never undergone any HIV testing. Seventeen (71\%) people reported having sex without a condom, one participant was in an open relationship and had contacts with various partners.

Eleven participants reported having done one test, one person tested twice. All tested negative for HIV. None of the persons tested reported any difficulty or problem with administering the test or reading its result. All participants considered this form of testing as easy and very accessible. Among all those who were provided with the tests, for 12 people there was no feedback as to whether the test was performed seksualnej, czasu od sytuacji ryzykownej, formy zachowań ryzykownych (kontakty seksualne, przyjmowanie substancji psychoaktywnych drogą iniekcji czy kontakt z krwią) oraz czy wcześniej było wykonywane badanie HIV. Kwestionariusz nie uwzględniał pytań dotyczących przebytych innych chorób przenoszonych drogą płciową.

Każda osoba włączona do badania otrzymywała dwa testy w kierunku HIV (łącznie przekazano 48 testów, Tabela I). Do testu dołączona była instrukcja jego zastosowania oraz numer bezpłatnej infolinii prowadzonej przez Fundację Edukacji Społecznej dotyczącej testowania w kierunku HIV. Każdy uczestnik badania mógł uzyskać tam szczegółowe informacje o sposobie wykonania testu oraz o prawidłowej interpretacji otrzymanego wyniku. W przypadku reaktywnego wyniku testu oferowane było wsparcie.

\section{WYNIKI}

W okresie od czerwca 2020 r. do marca 2021 r. testy zostały zaproponowane i przekazane 24 osobom, w tym 11 kobietom i 11 mężczyznom, dla dwóch osób nie podano płci (Tabela II).

Do badania włączane były osoby powyżej 18 roku życia. Średnia wieku wynosiła 35 lat (23-68). Kryterium włączenia było posiadanie partnera żyjącego z HIV (nowo zdiagnozowanym), będącego pod opieką poradni nabytych niedoborów odporności. Trzy osoby zakażone miały wykrywalny poziom wiremii (VL: 39 (kopii/ml), 1030 (kopii/ml), 7200000 (kopii/ ml). Wszyscy partnerzy osób zakażonych HIV oprócz testu otrzymywali także informację o innych formach zróżnicowanej profilaktyki, w tym możliwości postępowania przed ekspozycją na zakażenie HIV i po niej (PrEP, PEP), zabezpieczaniu się prezerwatywą, szczególnie w sytuacji posiadania partnera $\mathrm{z}$ oznaczalnym poziomem wiremii HIV. Uczestnicy badania otrzymywali także ulotkę informacyjną dotycząca badania PARTNER i kampanii $\mathrm{U}=\mathrm{U}$ (ang. Undetectable $=\mathrm{Un}-$ transmittable, co znaczy Niewykrywalny=Niezakaźny).

Wśród osób, które otrzymały testy było 20 osób deklarujących orientację heteroseksualną, dwie osoby homoseksualną, dla dwóch nie podano informacji o orientacji (Tabela II). Wśród osób, które otrzymały test do samodzielnego wykonania, 11 (46\%) osób nie wykonywało nigdy wcześniej badań w kierunku HIV. 17 (71\%) osób potwierdziło podejmowanie kontaktów bez prezerwatywy, jedna z badanych osób była w związku otwartym i miała kontakty z różnymi partnerami.

Jedenaście osób przekazało informacje, że wykonało jeden test, jedna osoba zrobiła testy dwukrotnie. Wszyscy uzyskali wynik ujemny. Żadna z osób wy- 
Table II. Study group profile

Tabela II. Charakterystyka badanej grupy

\begin{tabular}{|l|c|c|}
\hline & $\begin{array}{c}\text { Newly diagnosed } \\
\text { HIV persons }\end{array}$ & $\begin{array}{c}\text { Sexual partners } \\
\text { of newly } \\
\text { diagnosed HIV } \\
\text { persons }\end{array}$ \\
\hline Sex & 8 & 11 \\
Female & 16 & 11 \\
Male & - & 2 \\
No data & & \\
\hline Sexual & & 20 \\
orientation & & 2 \\
Heterosexual & & 0 \\
Homosexual & & 2 \\
Bisexual & & \\
No data & & \\
\hline
\end{tabular}

\section{DISCUSSION}

The pilot program described above proves that selftesting HIV kits are an acceptable and much needed testing method. Many newly diagnosed HIV persons had a partner who had not been tested for HIV.

This confirms previous observations indicating that there is a need for better access to diverse HIV testing methods, including self-testing kits $(10,11)$. HIV tests should be accessible and quick, especially to the particularly vulnerable populations at risk of infection, such as partners of newly diagnosed HIV persons. Testing should be available at medical facilities, private laboratories, as well as the Counselling and Testing Centres or European checkpoints. The states should make self-testing available, without fear of embarrassment, with your partner or in the privacy of your own home. For effective HIV prevention, rapid diagnostic testing and its integration into healthcare are key (12). HIV testing only requires basic knowledge and does not need to be performed by a health professional.

Introducing self-testing HIV kits in the case of partners of newly diagnosed HIV persons allows for potential detection of infection even in a situation where the access to testing is limited due to, for example, a SARS-CoV-2 epidemic. Such measures are necessary for maintaining optimum access to HIV testing, in particular for those at the highest risk of infection (13).

A randomised controlled trial conducted in Seattle on a group of 230 high-risk men having sex with men showed that men randomly assigned to a self-testing group reported a higher number of HIV tests during follow-up than those randomised to testing as usual, representing an average increase of 1.7 tests per participant over 15 months. This study confirms that the availability of self-testing kits gives easy access to konujących badania nie zgłosiła trudności ani problemów z jego wykonaniem ani z odczytaniem wyniku. Wszystkie osoby badane uznały tę formę testowania jako łatwą i bardzo przystępną. Wśród przekazanych wszystkich testów, od 12 osób nie uzyskano informacji zwrotnej czy badanie zostało wykonane.

\section{DYSKUSJA}

W powyższym pilotażowym programie wykazano, że testy w kierunku HIV do samodzielnego testowania są akceptowalną i potrzebną formą wykonywania badań. Większość osób z nowo postawionym rozpoznaniem HIV miała partnera/partnerkę która nie była badana w kierunku HIV.

Potwierdza to wcześniejsze doniesienia wskazujące na potrzebe rozszerzenia dostępności różnych form badania w kierunku HIV, także o testy do samodzielnego wykonania $(10,11)$. Testowanie w kierunku HIV powinno być dostępne i szybkie, szczególnie dla populacji osób szczególnie narażonych na zakażenie, jak partnerzy osób z nowo wykrytym zakażeniem. Możliwość wykonania testu powinna być dostępna w placówkach medycznych, prywatnych laboratoriach, jak i w punktach konsultacyjno-diagnostycznych czy europejskich checkpointach. Kraje powinny udostępnić także możliwość samodzielnego badania, bez skrępowania, ze swoim partnerem, czy w zaciszu domowym. W skutecznym przeciwdziałaniu HIV ważna jest szybka diagnostyka i włączenie do opieki medycznej (12). Testowanie w kierunku HIV wymaga podstawowej wiedzy i nie musi być wykonywane przez pracownika medycznego.

Wprowadzenie testów w kierunku HIV do samodzielnego wykonania przez partnerów osób z noworozpoznanym zakażeniem daje możliwość wykrycia zakażenia pomimo ryzyka ograniczonego dostępu do diagnostyki, na przykład spowodowanego przez epidemię SARS-CoV-2. Tego typu działania są potrzebne do utrzymania optymalnego dostępu do diagnostyki HIV, szczególnie dla osób narażonych na największe ryzyko zakażenia (13).

Przeprowadzone randomizowane badania w Seattle w grupie 230 mężczyzn mających seks z mężczyznami z wysokim ryzykiem zakażenia HIV wykazały, że mężczyźni przydzieleni losowo do samotestowania zgłaszali wykonanie większej liczby testów na HIV w okresie obserwacji niż ci, którzy zostali losowo przydzieleni do testów wykonywanych metodą konwencjonalną, co stanowiło średni wzrost o 1,7 testu na uczestnika w ciągu 15 miesięcy. Badania te potwierdzają, że dostępność testów do samodzielnego wykonania daje możliwość łatwego dostępu do badania w kierunki HIV, dzięki czemu większa liczba osób wykonuje testy (14). 
HIV tests, which leads to increased testing frequency (14).

Promoting and popularising the introduction of simple and widely available testing methods is particularly important, especially bearing in mind that half of the HIV positive people in Poland are diagnosed late $(15,16)$.

Improving the availability of tests for HIV and other sexually transmitted diseases and developing longterm prophylactic strategies are particularly important for key populations at risk of HIV infections. A multisite randomised controlled trial studied the attitudes and preferences of $272 \mathrm{HIV}$-negative men. The results of the trial show that $21.7 \%$ had previously tested with an HIV self-testing kit. They preferred a rapid oral mucosal transudate test - a gum swab - 96\%, to a finger prick test $-69 \%$. However, if the test had given results for other sexually transmitted diseases, their preference would have been for a blood test $86 \%$. The study showed a high level of acceptability of self-testing, as $93 \%$ reported it was likely they would use self-testing kits to test partners in the future. Only $5 \%$ of men reported problems with performing the test (17).

A European study conducted in 2020 showed a considerable decrease, by $95 \%$, of HIV testing available in the period between March and May 2020 and a $58 \%$ decrease in the period between June and August (18).

A comparative analysis of the HIV detection rate conducted between 2015 and the 2nd quarter of 2020 in Japan showed that the SARS-CoV-2 pandemic had a considerable impact on the decrease in HIV testing and detection rate. The study shows that the number of tests performed by public healthcare facilities fell considerably in the 2nd quarter of 2020, having decreased by over three times compared to the previous year's results: 9,584 vs 35,908 the year before (19). The researchers emphasise the importance of self-testing in the setting of limited access to standard testing methods, which is instrumental in getting a clear epidemiology picture of HIV infections during the SARS-CoV-2 pandemic.

The lack of access to HIV testing increases the risk of health deterioration and progression of the disease to AIDS, as well as of unknowingly exposing the partner to infection. The fact that self-testing kits are reliable, acceptable and invaluable for a fast diagnosis has been proved by numerous studies $(8,20-22)$. As the above-described pilot program shows, we may expect a similar reception of self-testing kits in Poland as well. It is imperative for people using HIV self-testing kits to know how much time needs to pass for the test result to be reliable.
Działania promujące i upowszechniające wprowadzanie łatwych i szeroko dostępnych form testowania są szczególnie istotne, biorąc pod uwagę, że w Polsce ponad połowa osób zakażonych HIV jest późno zdiagnozowana $(15,16)$.

Zwiększenie dostępności do diagnostyki w kierunku HIV i innych chorób przenoszonych drogą płciową oraz długofalowe strategie profilaktyczne są szczególnie potrzebne dla kluczowych populacji narażonych na zakażenie HIV. W wieloośrodkowym randomizowanym badaniu zbadano postawy i preferencje 272 niezakażonych HIV mężczyzn. Wyniki tego badania wskazują, że $21,7 \%$ badało się wcześniej testami do samodzielnego badania w kierunku HIV. Preferowali oni szybkie testy z przesączu/wymaz z jamy ustnej $96 \%$, zamiast testów z krwi z palca $-69 \%$. Jednak, gdyby badanie wykazywało również wyniki w kierunku innych chorób przenoszonych drogą płciową, preferowaliby badanie z krwi $-86 \%$. Badanie wykazało duży poziom akceptowalności testów do samodzielnego wykonania badania, gdyż 93\% badanych zgłosiło prawdopodobieństwo wykonania szybkich testów do samodzielnego wykonania przez swoich partnerów w przyszłości. Jedynie 5\% mężczyzn zgłosiło problemy z wykonaniem testu (17).

Europejskie badania przeprowadzone w 2020 wskazały na znaczący spadek, o 95\%, dostępności diagnostyki HIV w okresie marzec - maj 2020 i 58\% spadek w okresie czerwiec - sierpień (18).

Przeprowadzona analiza porównawcza wykrywalności HIV od 2015 r. do drugiego kwartału 2020 r. w Japonii pokazała, że pandemia SARS-CoV-2 miała znaczący wpływ na spadek testowania i wykrywalności zakażeń HIV. Z badań wynika, że liczba testów wykonywanych przez publiczne placówki zdrowia znacząco spadła w II kwartale 2020 r., zmniejszając się ponad trzykrotnie w porównaniu do wyników sprzed roku: 9584 vs 35908 rok wcześniej (19). Badacze podkreślają istotę samodzielnych testów przy ograniczonym dostępie do standardowych form testowania, które są niezbędne do zrozumienia jasnego obrazu epidemicznego zakażeń HIV podczas pandemii SARS-CoV-2.

Brak dostępu do badań w kierunku HIV zwiększa ryzyko pogorszenia zdrowia i progresji choroby do AIDS, jak również nieświadomego narażenia partnerów na zakażenie. Skuteczność, akceptowalność i wartość testów do samodzielnego wykonania w szybkiej diagnozie potwierdziły liczne prace badawcze $(8,20-$ 22). Jak wskazuje opisany powyżej program pilotażowy takiego ich odbioru możemy spodziewać się także w Polsce. Ważne jest, aby osoby wykonujące testy samodzielne miały wiedzę dotyczącą czasu po jakim wynik tego testu jest wiarygodny. 
According to the recommendations of the Polish AIDS Society published in 2021, HIV self-testing kits should be one of the testing methods available in Poland (9).

The pilot study was possible owing to the extensive initiatives undertaken by the Foundation of Social Education and their HIV testing helpline. It not only helped to provide tests to participants but also gave the tested persons access to reliable information, expert knowledge, as well as support in the case of an uncertain or reactive test result.

The study was carried out at one site only, on a small test group, and constituted a pilot program. The study was based only on HIV patients' reports, which considerably limited the reliability of the data collected. Its results provide a basis for further research and the introduction of a systemic approach to the popularisation of self-testing in Poland. The contracts of infectious diseases physicians and AIDS outpatient clinics do not cover pre-exposure prophylaxis or testing.

\section{CONCLUSIONS}

The HIV self-tests offer a fast and accurate preliminary diagnostic procedure without the limitations of a visit to a medical facility or another testing centre. They provide a broader range of HIV testing measures, they are considered simple to apply and are readily accepted by the partners of newly diagnosed HIV persons.

Acknowledgments. The study was conducted with support from: the educational grant and sponsorship from: Gilead Sciences Poland Sp. z o.o. and GSK.

\section{REFERENCES}

1. Raben D, Hoekstra M, Combs L, et al. A call to action toward integrated testing and earlier care for viral hepatitis, HIV, STIs and TB. HIV Med 2020;6:403-408

2. Kowalska JD, Kase K, Vassilenko A, et al. The characteristics of HIV-positive patients with mild/ asymptomatic and moderate/severe course of COVID-19 disease - A report from Central and Eastern Europe. Int J Infect Dis 2021;104:293-296

3. Rosińska M, Marzec-Bogustawska A, Janiec J, et al. High Percentage of Recent HIV Infection Among HIV-Positive Individuals Newly Diagnosed at Voluntary Counseling and Testing Sites in Poland. AIDS Res Hum Retroviruses [Internet]. 2013;29(5):805-13. Available from: http://online. liebertpub.com/doi/abs/10.1089/aid.2012.0314

4. Rosińska M, Simmons R, Marzec-Bogusławska A, et al. Relating HIV testing patterns in
Zgodnie z rekomendacjami Polskiego Towarzystwa Naukowego AIDS opublikowanymi w 2021 roku, testy do samodzielnego badania w kierunku HIV powinny być jedną $z$ dostępnych form testowania w Polsce (9).

Pilotażowe badanie było możliwe dzięki szerszym działaniom Fundacji Edukacji Społecznej i prowadzenia infolinii dotyczącej testowania. Pozwoliło to nie tylko przekazać testy, ale również zapewnić osobom badanym możliwość uzyskania rzetelnej i fachowej informacji, a także wsparcia $\mathrm{w}$ sytuacji niejasnego bądź też, reaktywnego wyniku testu.

Badanie zostało przeprowadzone tylko w jednym ośrodku, na małej grupie i miało charakter pilotażowy. Badanie opierało się jedynie na deklaracjach osób zakażonych HIV, co stanowi znaczące ograniczenie wiarygodności zebranych danych. Jego wyniki są podstawą do dalszych prac i wprowadzenia systemowego podejścia do upowszechnienia samodzielnego testowania w Polsce. Poradnie niedoborów odporności i lekarze chorób zakaźnych nie mają w swoich kontraktach prowadzenia postępowania przed ekspozycją ani prowadzenia testowania.

\section{WNIOSKI}

Testy w kierunki HIV do samodzielnego wykonania pozwalają na szybką i łatwą diagnostykę wstępną, której nie ogranicza konieczność zgłaszania się do placówki medycznej, czy innego punktu oferującego testowanie. Pozwalają na rozszerzenie możliwości testowania w kierunku HIV, są postrzegane jako łatwe do wykonania i chętnie akceptowane przez partnerów osób z nowym rozpoznaniem HIV.

Podziękowanie: Badanie zostało przeprowadzone w ramach wsparcia: grantu edukacyjnego i sponsoringu firm: Gilead Sciences Poland Sp. z o.o. i GSK.

Poland to risky and protective behaviour. AIDS Care - Psychol Socio-Medical Asp AIDS/HIV 2016;28(4):423-31.

5. European Centre for Disease Prevention and Control (ECDC), WHO Regional Office for Europe. (WHO/Europe). HIV/AIDS surveillance in Europe 2020 - 2019 data. Copenhagen: WHO/ Europe; 2020. Available from: https://www.euro. who.int/en/publications/abstracts/hiv.

6. Easter P, Johnson C, Figueroa C, et al.. HIV and hepatitis testing: Global progress, challenges, and future directions. AIDS Rev 2016;18(1):3-14

7. Stevens DR, Vrana CJ, Dlin RE, et al. A Global Review of HIV Self-testing: Themes and Implications. T. 22, AIDS and Behavior 2018; 22(2):497-512 
8. WHO. Guidelines on HIV self-testing and partner notification [Internet]. WHO. 2016. Available from: http://apps.who.int/iris/bitstre am/10665/251655/1/9789241549868-eng.pdf?ua=1

9. http://ptnaids.pl/images/pliki/wytyczne AIDS_2021.pdf [Internet]. Available from: http:// ptnaids.pl/images/pliki/wytyczne_AIDS_2021. pdf

10. Lazarus J V., Safreed-Harmon K, Barton SE, et al. Beyond viral suppression of HIV - the new quality of life frontier. T. 14, BMC Medicine 2016;14:94

11. Ibitoye M, Frasca T, Giguere R, Carballo-Diéguez A. Home testing past, present and future: Lessons learned and implications for HIV home tests. T. 18, AIDS and Behavior 18(5):933-49

12. Kowalska JD, Wójcik G, Rutkowski J, et al . Modelling the cost-effectiveness of HIV care shows a clear benefit when transmission risk is considered in the calculations - A message for Central and Eastern Europe. PLoS One 2017;12(11).

13. Frith L. HIV self-testing: a time to revise current policy. Lancet 2007;369(9557):243-5.

14. Katz DA, Golden MR, Hughes JP, et al. HIV Selftesting increases HIV testing frequency in highrisk men who have sex with men: A randomized controlled trial. W: Journal of Acquired Immune Deficiency Syndromes 2018;78(5):505-512

15. Ankiersztejn-Bartczak M, Firlag-Burkacka E, Czeszko-Paprocka H, et al. Factors responsible for incomplete linkage to care after HIV diagnosis: Preliminary results from the Test and Keep in Care (TAK) project. HIV Med 2015;16(2):88-94.

16. Wójcik-Cichy K, Jabłonowska O, Piekarska A, et al. The high incidence of late presenters for HIV/ AIDS infection in the Lodz province, Poland in the years 2009-2016: we are still far from the UNAIDS 90\% target. AIDS Care - Psychol SocioMedical Asp AIDS/HIV 2018;30(12):1538-1541

17. Sarah Iribarren, Cody Lentz, Alan Z Sheinfil, et al. Using an HIV Self-test Kit to Test a Partner:
Attitudes and Preferences Among High-Risk Populations. AIDS Behav 2020;24(11):3232-43.

18. Simões D, Stengaard AR, Combs L, et al. Impact of the COVID-19 pandemic on testing services for HIV, viral hepatitis and sexually transmitted infections in the WHO european region, March to August 2020. Euro Surveill 2020;25(47):2001943

19. Ejima K, Koizumi Y, Yamamoto $\mathrm{N}$, et al. HIV Testing by Public Health Centers and Municipalities and New HIV Cases During the COVID-19 Pandemic in Japan. J Acquir Immune Defic Syndr. 2021;87(2):e182-7.

20. Ngure K, Heffron R, Mugo N, et al. Feasibility and acceptability of HIV self-testing among preexposure prophylaxis users in Kenya. J Int AIDS Soc 2017;20(1): 21234

21. Myers JE, El-Sadr WM, Zerbe A, Branson BM. Rapid HIV self-testing. AIDS [Internet]. 2013;27(11):1687-95. Available from: http://content. wkhealth.com/linkback/openurl?sid=WKPTLP: landingpage \&an $=00002030-201307170-00001$

22. Sharma M, Ying R, Tarr G, Barnabas R. Systematic review and meta-analysis of community and facility-based HIV testing to address linkage to care gaps in sub-Saharan Africa. Nature 2015;528(7580):p77-85

\author{
Received: 14.07.2021 \\ Accepted for publication: 08.11.2021 \\ Otrzymano: 14.07.2021 r. \\ Zaakceptowano do publikacji: 08.11.2021 r.
}

\section{Address for correspondence:}

Adres do korespondencji:

dr n. społ. Magdalena Ankiersztejn-Bartczak

Fundacja Edukacji Społecznej,

ul. Sewerynów 4/100, 00-331 Warszawa

Tel: 692478229,

E-mail: m.bartczak@fes.edu.pl. 